DOI: $10.20535 / \mathrm{kpi}-\mathrm{sn} .2020 .2 .205124$

UDC 519.2, 519.8

\author{
I. Nesteruk ${ }^{1,2 *}$, I. Kudybyn ${ }^{3}$, G. Demelmair ${ }^{4}$ \\ ${ }^{1}$ Institute of Hydromechanics, National Academy of Sciences of Ukraine, Kyiv, Ukraine \\ ${ }^{2}$ Igor Sikorsky Kyiv Polytechnic Institute, Kyiv, Ukraine \\ ${ }^{3}$ Institute of Hydromechanics, National Academy of Sciences of Ukraine, Kyiv, Ukraine \\ ${ }^{4}$ Gymnasium Ried im Innkreis, Austria \\ *corresponding author: inesteruk@yahoo.com
}

\title{
GLOBAL STABILIZATION TRENDS OF COVID-19 PANDEMIC
}

Background. The coronavirus COVID-19 pandemic is of great concern. A detailed scientific analysis of this phenomenon is still to come, but now it is urgently needed to evaluate and compare the disease dynamics in order to improve the quarantine activities and the level of individual protection, to speed the rate of isolation of infected persons, etc. In mid-March 2020, the WHO reported a sharp exponential increase in the number of COVID-19 cases in the world. Therefore, the study of the dynamics of the pandemic continues to attract the interest of researchers. Some works on comparing the epidemic dynamics in Italy, mainland China, Spain, Germany, France, Switzerland, USA, South Korea and some global trends have already been published. However, the receipt of new data requires constant analysis of the pandemic dynamics.

Objective. In this paper we compare the pandemic dynamics in March and April, 2020 for different countries in Europe, USA, regions and worldwide and try to estimate some global trends.

Methods. We use official data about the accumulated numbers of confirmed COVID-19 cases in different countries and worldwide from WHO daily situation reports. In order to compare the epidemic dynamics in different countries, different time synchronization procedures and comparing with the exponential growth are used.

Results. For Italy, Spain, Germany, Switzerland, France and USA, the epidemic dynamic in March, 2020 was compared with the situation in the Republic of Korea. The epidemic developments in Ukraine, Austria, their neighboring countries and global trends were analyzed.

Conclusions. The situation with the COVID-19 pandemic is still threatening. But may be the dynamics in April, 2020 gives some hope for its stabilization at least in the countries with proper quarantine measures, fast detection and isolation of sick persons. The final sizes and durations of epidemic can be very different for different countries. Repeated outbreaks are possible and already occurring, but they will no longer be so severe, primarily because we have learned to better identify and isolate infected persons.

Keywords: coronavirus COVID-19 pandemic; coronavirus 2019-nCoV; statistical methods.

\section{Introduction}

The coronavirus COVID-19 pandemic is of great concern [1]. In particular, in mid-March 2020, the WHO reported a sharp exponential increase in the number of cases in the world. Therefore, the study of the dynamics of the pandemic, begun in [2-10], continues to attract the interest of researchers. Some previous efforts to compare the epidemic dynamics in Italy and mainland China has been done in [2]. In [3] the global development was analyzed. The comparison of the pandemic development in Italy, Spain, Germany, France, Switzerland, USA and South Korea has been presented in [4]. In this paper we will analyze the global prospects of Covid-19 pandemic dynamics with the use the official WHO daily data [1] for the confirmed accumulated number of cases in March and April, 2020 and discuss some SIR estimations for different countries presented in $[5,7-9]$.

(C) The Author(s).

The article is distributed under the terms of the license CC BY 4.0.

\section{Materials and Methods}

Data. We will use official data about the accumulated numbers of confirmed COVID-19 cases in different countries and worldwide from WHO daily situation reports (numbers 41-91) [1]. We will use the WHO classification for regions without territories. Since the recent situation in mainland China and the Republic of Korea is stable, we will use the global statistics without cases in these two regions.

For example, the official data about the accumulated number of confirmed cases in Italy, Spain, France, Germany, Switzerland, USA, South Korea $V_{j}$ and corresponding moments of time $t_{j}$ and $t_{e j}$ are shown in Tables 1 and 2. The number of cases confirmed in Ukraine and its neighboring countries is shown in Table 3. 
Table 1. Official cumulative numbers of confirmed cases in the Republic of Korea

\begin{tabular}{|c|c|c|c|c|c|}
\hline $\begin{array}{c}\text { Day in } \\
\text { February, 2020 }\end{array}$ & $\begin{array}{c}\text { Time } \\
\text { moment } t_{j}\end{array}$ & $\begin{array}{c}\text { Accumulated number } \\
\text { of cases in the Republic } \\
\text { of Korea } V_{j}[3]\end{array}$ & $\begin{array}{c}\text { Day in March, } \\
2020\end{array}$ & $\begin{array}{c}\text { Time } \\
\text { moment } t_{j}\end{array}$ & $\begin{array}{c}\text { Accumulated } \\
\text { number of cases in } \\
\text { the Republic of } \\
\text { Korea } V_{j}[3]\end{array}$ \\
\hline 17 & -1 & 31 & 1 & 12 & 4212 \\
18 & 0 & 51 & 2 & 13 & 4812 \\
19 & 1 & 104 & 3 & 14 & 5328 \\
20 & 2 & 204 & 4 & 15 & 5766 \\
21 & 3 & 346 & 5 & 16 & 6284 \\
22 & 4 & 602 & 7 & 17 & 6767 \\
23 & 5 & 763 & 8 & 19 & 7134 \\
24 & 6 & 977 & 9 & 20 & 7382 \\
25 & 7 & 1261 & 10 & 21 & 7513 \\
26 & 8 & 1766 & 11 & 22 & 7755 \\
27 & 9 & 2337 & 12 & 23 & 7869 \\
28 & 10 & 3150 & 13 & 24 & 7979 \\
29 & 11 & 3736 & 14 & 25 & 8086 \\
\hline
\end{tabular}

Note. The information from [1]. The corresponding time moments $t_{j}$ and the accumulated confirmed numbers of cases $V_{j}$ in South Korea.

Table 2. The number of cases in Italy, Spain, France, Germany, Switzerland and USA used for comparisons and the results of calculations

\begin{tabular}{|c|c|c|c|c|c|c|c|}
\hline $\begin{array}{c}\text { Day in February } \\
\text { and March, 2020 }\end{array}$ & Italy & Germany & France & Spain & Switzerland & USA & $t_{e j}$ \\
\hline 22 & $\mathbf{7 6}$ & 16 & 12 & 2 & 0 & 35 & $\mathbf{0}$ \\
\hline 23 & 124 & 16 & 12 & 2 & 0 & 35 & 1 \\
\hline 24 & 229 & 16 & 12 & 2 & 0 & 53 & 2 \\
\hline 25 & 322 & 18 & 12 & 2 & 1 & 53 & 3 \\
\hline 26 & 400 & 21 & 18 & 12 & 1 & 59 & 4 \\
\hline 27 & 650 & 26 & 38 & 25 & 6 & 59 & 5 \\
\hline 28 & 888 & $\mathbf{5 7}$ & 57 & 32 & 10 & 62 & $\mathbf{6}$ \\
\hline 29 & 1128 & 100 & $\mathbf{5 7}$ & 45 & 18 & 62 & $\mathbf{7}$ \\
\hline 1 & 1689 & 129 & 100 & $\mathbf{4 5}$ & 24 & 62 & $\mathbf{8}$ \\
\hline 2 & 2036 & 157 & 191 & 114 & 30 & $\mathbf{6 4}$ & $\mathbf{9}$ \\
\hline 3 & 2502 & 196 & 212 & 151 & 37 & 108 & 10 \\
\hline 4 & 3089 & 262 & 282 & 198 & $\mathbf{5 6}$ & 129 & $\mathbf{1 1}$ \\
\hline 5 & 3858 & 534 & 420 & 257 & 86 & 148 & 12 \\
\hline 6 & 4636 & 639 & 613 & 374 & 209 & 213 & 13 \\
\hline 7 & 5883 & 795 & 706 & 430 & 264 & 213 & 14 \\
\hline 8 & 7375 & 1112 & 1116 & 589 & 332 & 213 & 15 \\
\hline 9 & 9172 & 1139 & 1402 & 1024 & 332 & 472 & 16 \\
\hline 10 & 10149 & 1296 & 1774 & 1639 & 491 & 696 & 17 \\
\hline 11 & 12462 & 1567 & 2269 & 2140 & 645 & 987 & 18 \\
\hline 12 & 15113 & 2369 & 2860 & 2965 & 858 & 1264 & 19 \\
\hline 13 & 17660 & 3062 & 3640 & 4231 & 1125 & 1678 & 20 \\
\hline 14 & 21151 & 3795 & 4469 & 5753 & 1359 & 1678 & 21 \\
\hline
\end{tabular}


Table continuation

\begin{tabular}{|c|c|c|c|c|c|c|c|}
\hline Characteristic & Italy & Germany & France & Spain & Switzerland & USA & $t_{e j}$ \\
\hline $\begin{array}{c}\text { Mortality rate (\%), } \\
\text { March 14, 2020 }\end{array}$ & 6.81 & 0.21 & 2.04 & 2.36 & 0.81 & 2.44 & - \\
\hline$d_{t}$ & 0.549 & 0.154 & 0.154 & -0.179 & 0.129 & 0.312 & - \\
\hline
\end{tabular}

Note. The information about the confirmed accumulated number of cases from [1]. The mortality rate was calculated with the use of numbers for March 14, 2020 (the situation report dated March 15, 2020 [1]). The corresponding time moments $t_{e j}$ are shown in the last column. The values corresponding the beginning of the epidemic outbreak are shown in bold. The values $d_{t}$ were calculated with the use of formula (2).

Table 3. Official cumulative numbers of confirmed cases in Ukraine, Moldova, Poland, Slovakia, Hungary, Romania, Belarus, and Russian Federation (RF) [1]

\begin{tabular}{|c|c|c|c|c|c|c|c|c|}
\hline $\begin{array}{l}\text { Day in February } \\
\text { and March, } 2020\end{array}$ & Ukraine & Slovakia & Hungary & Moldova & Romania & Poland & Belarus & RF \\
\hline 21 & 0 & 0 & 0 & 0 & 0 & 0 & 0 & 2 \\
\hline 22 & 0 & 0 & 0 & 0 & 0 & 0 & 0 & 2 \\
\hline 23 & 0 & 0 & 0 & 0 & 0 & 0 & 0 & 2 \\
\hline 24 & 0 & 0 & 0 & 0 & 0 & 0 & 0 & 2 \\
\hline 25 & 0 & 0 & 0 & 0 & 0 & 0 & 0 & 2 \\
\hline 26 & 0 & 0 & 0 & 0 & 1 & 0 & 0 & 2 \\
\hline 27 & 0 & 0 & 0 & 0 & 1 & 0 & 1 & 2 \\
\hline 28 & 0 & 0 & 0 & 0 & 3 & 0 & 1 & 2 \\
\hline 29 & 0 & 0 & 0 & 0 & 3 & 0 & 1 & 2 \\
\hline 1 & 0 & 0 & 0 & 0 & 3 & 0 & 1 & 2 \\
\hline 2 & 0 & 0 & 0 & 0 & 3 & 0 & 1 & 3 \\
\hline 3 & 1 & 0 & 0 & 0 & 4 & 1 & 1 & 3 \\
\hline 4 & 1 & 0 & 2 & 0 & 4 & 1 & 6 & 3 \\
\hline 5 & 1 & 0 & 2 & 0 & 6 & 1 & 6 & 4 \\
\hline 6 & 1 & 1 & 5 & 0 & 7 & 5 & 6 & 7 \\
\hline 7 & 1 & 3 & 7 & 1 & 13 & 6 & 6 & 7 \\
\hline 8 & 1 & 5 & 9 & 1 & 15 & 11 & 6 & 7 \\
\hline 9 & 1 & 7 & 9 & 1 & 15 & 16 & 6 & 7 \\
\hline 10 & 1 & 7 & 13 & 3 & 25 & 22 & 9 & 7 \\
\hline 11 & 1 & 10 & 13 & 4 & 48 & 44 & 12 & 20 \\
\hline 12 & 3 & 21 & 16 & 4 & 48 & 49 & 12 & 34 \\
\hline 13 & 3 & 30 & 19 & 8 & 64 & 64 & 21 & 34 \\
\hline 14 & 3 & 44 & 32 & 12 & 123 & 111 & 21 & 34 \\
\hline 15 & 3 & 61 & 39 & 23 & 158 & 150 & 36 & 63 \\
\hline 16 & 7 & 72 & 50 & 29 & 158 & 150 & 36 & 93 \\
\hline 17 & 14 & 97 & 50 & 30 & 184 & 246 & 36 & 93 \\
\hline 18 & 16 & 105 & 58 & 36 & 246 & 287 & 46 & 147 \\
\hline 19 & 16 & 123 & 73 & 49 & 260 & 325 & 46 & 199 \\
\hline 20 & 26 & 137 & 85 & 66 & 308 & 425 & 57 & 253 \\
\hline 21 & 47 & 178 & 131 & 80 & 367 & 536 & 76 & 306 \\
\hline
\end{tabular}


Time synchronization procedures. To compare the epidemic dynamics in different countries a time synchronization is necessary. In paper [2] the linear interpolation for the number of cases in mainland China (registered during two days) was used to compare with epidemic outbreak in Italy and Europe. It this paper we will use more precise quadratic interpolation for the number of cases confirmed in three days February 17-19, 2020 in the Republic of Korea in order to compare with the initial epidemic dynamics in some other countries.

To calculate the number of days from start of the epidemic outbreak which is different for every country (see values marked in red in the last column of Table 2), it is necessary to compare it with the data set listed in Table 1. To increase the accuracy, we let this number to be non-integer. To calculate the corresponding time difference $d_{t}$, the parabolic interpolation for the initial number of cases $V$ in South Korea will be used. The first three points in Table 1 yield the corresponding equation:

$$
V=a t^{2}+b t+51 ; a=16.5, b=36.5 \text {. }
$$

Then by putting into (1) the values $V=V_{b}$ for the number of cases at the starting day of the epidemic outbreak (shown in red in Table 2), the corresponding values $d_{t}$ were calculated for every country with the use of formula

$$
d_{t}=\frac{-b+\sqrt{b^{2}-4 a c}}{2 a} ; c=51-V_{b}
$$

which yields a solution to the quadratic equation (1). The calculated values of $d_{t}$ are shown in the last row of Table 2. Then the time moments for Italy have to be shifted by 0.549 days, for Germany by $6+0.154$ days and so on.

To compare the pandemic dynamics in Ukraine and its neighboring countries, the day of the first case appearance was taken as the zero day of the epidemic in each country. This simple method allows estimating the dynamics and comparing different countries with different days of the epidemic outbreak.

Exponential growth of the number of cases. For the initial stage of an epidemic the exponential growth of the number of cases is typical (see e.g., [6]):

$$
V=e^{\alpha t+\beta} .
$$

It means, that corresponding points in logarithmic scale follow the straight lines. Later the number of cases stabilizes and tends to some saturation level (see e.g., results of SIR simulations presented in [5, 7-9]).
Eq. (3) yields the linear dependence:

$$
\log V=\alpha t+\beta
$$

and the time of cases duplication:

$$
\tau=\frac{\log 2}{\alpha} .
$$

To estimate the values of parameters $\alpha$ and $\beta$, linear regression for the values $\log \left(V_{j}\right)$ may be used (see, e.g., [11]). Some results for periods of the pandemic exponential growth in March, 2020 can be found in [7]. The most rapid increase occurred in USA (the number of cases duplicates every 2.31 days). The European and global duplications rates were 2.91 and 3.65 days respectively. Without stabilization by mid-April 2020, 41 million cases could be expected in Europe; 38 millions in USA and 211 millions globally. Fortunately, after the end of March there was no exponential growth and these sad figures are no longer relevant.

\section{Results and discussion}

The data sets from Tables 1 and 2 synchronized with the use eqs. (1) and (2) are shown in the Fig. 1 by "stars" for countries in Europe and by "squares" for USA. The data for South Korea are shown by red line with "circles". Blue "stars" represent the sum of cases for 5 countries in Europe. It can be seen that in March, 2020 Italy, Spain, Germany, Switzerland and France had no chance for rapid stabilization of the number of cases. The situation in USA was not clear. Unfortunately, in this country very rapid increase of the number of cases occurred after March 15, 2020. Blue "stars" in the Fig. 1 still followed the straight line, therefore the number of cases in Europe increased exponentially between February 22 and March 14, 2020.

The application of the same simple procedure was illustrated for the epidemic outbreak in Austria. The number of cases in this country was $V_{b}=66$ on March 6, 2020. Let us suppose that epidemic in this country started on this day. Corresponding values are: $t_{e j}=13$ (see Table 2) and $d_{t}=0.3542$ (according to eq. (2)). If we want to know how looked the situation on March 15, 2020 (ninth day of the epidemic), we open the corresponding WHO report (number 56) and find there the number 959 for Austria. This figure has to be compared with the number of cases from Table 1, corresponding to the time moment $9+0.3542$. To avoid any additional calculations, let us take the value 2337 for comparison. Thus the situation in Austria did not look bad. On 
April 20, 2020 the number of cases in this country was 14783 and close to the saturation level 15108, predicted in [9].

The comparison of the pandemic dynamics in Ukraine and its neighboring countries with the use of the first case day are shown in Figs. 2 and 3 in two different scales. The synchronized data sets are shown in the Figs. 1 and 2 by "stars" for EU countries and by "circles" for other countries. Fig. 1 illustrates that the highest number of cases were confirmed in Poland, Romania and RF. We can compare the number of cases for the fixed day from the epidemic outbreak (for example, 14th day, when the information from all countries is available). The most rapid increase occurred in Poland, Slovakia and Moldova.

The situation in Ukraine did look very bad. But last three points in Fig. 2 illustrate that the number of cases in Ukraine increased very rapid. The further development of the situation showed that the number of cases in Ukraine exceeded those on Moldova. The slow epidemic development between March 3 and March 21, 2020 can be explained by the absence of proper PCR testing (many infected persons were not detected).

The accumulated number of cases confirmed in March and April, 2020 are shown in Figs. 4-7.

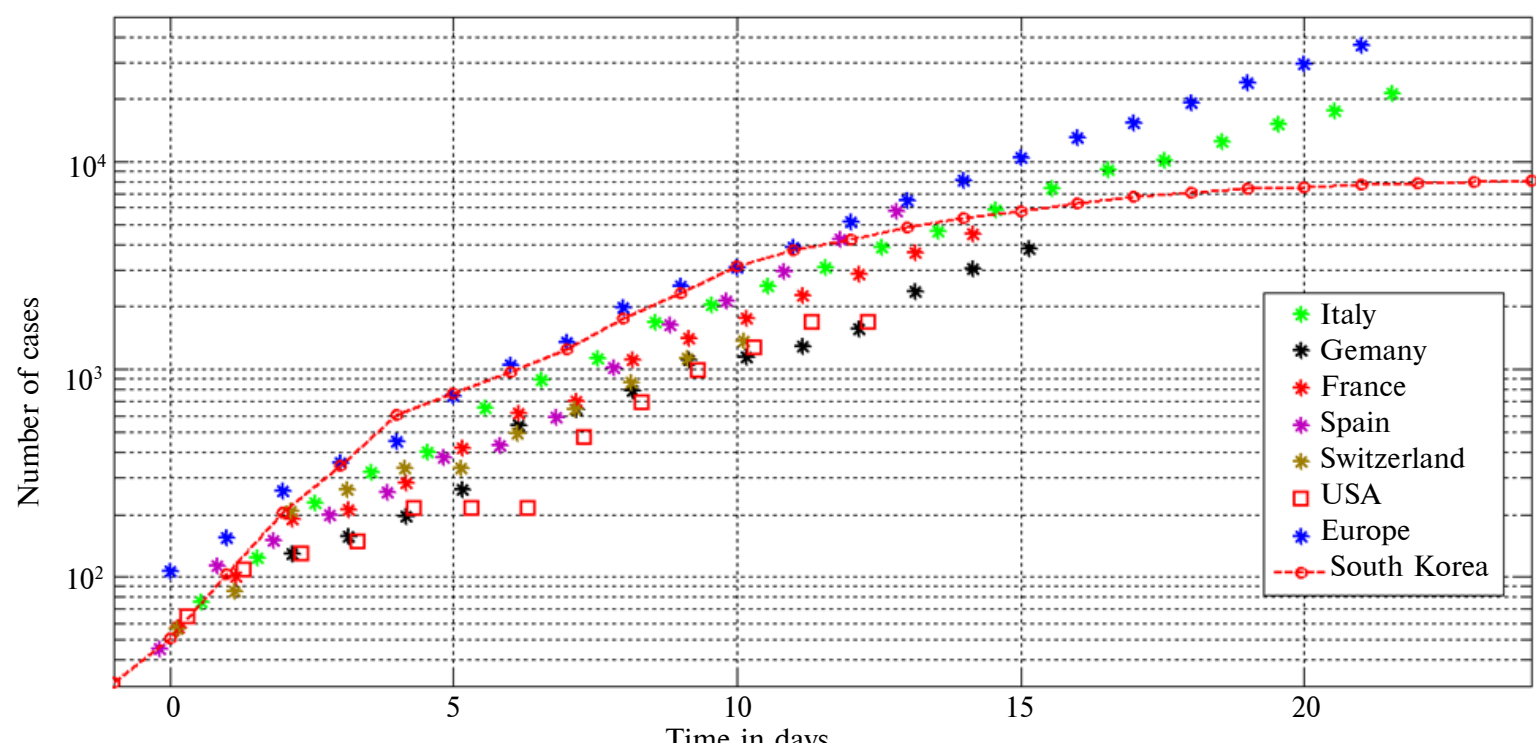

Fig. 1. The synchronized data sets for the accumulated confirmed number of cases versus time in days from the beginning of the epidemic outbreaks

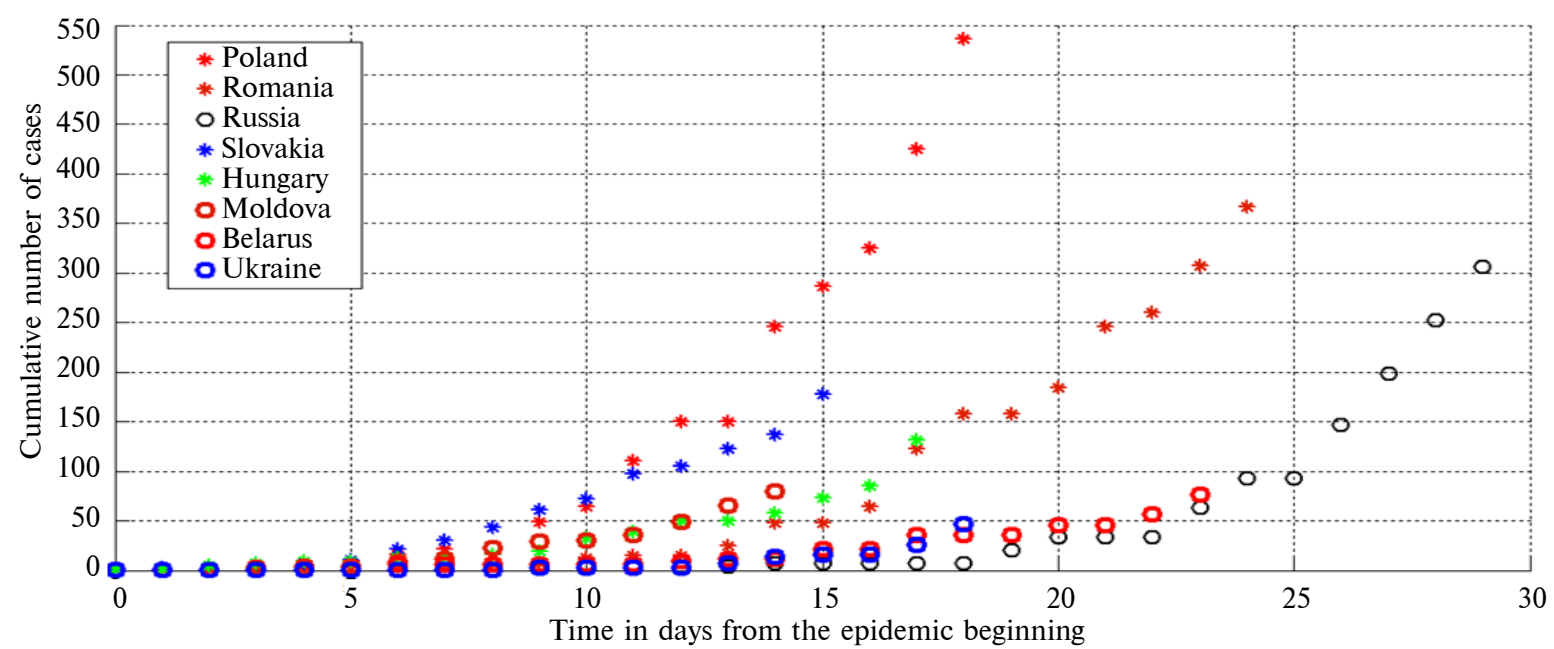

Fig. 2. The synchronized data sets for Ukraine and its neighboring countries versus time in days starting with the day when the first COVID-19 case was confirmed (linear scale) 


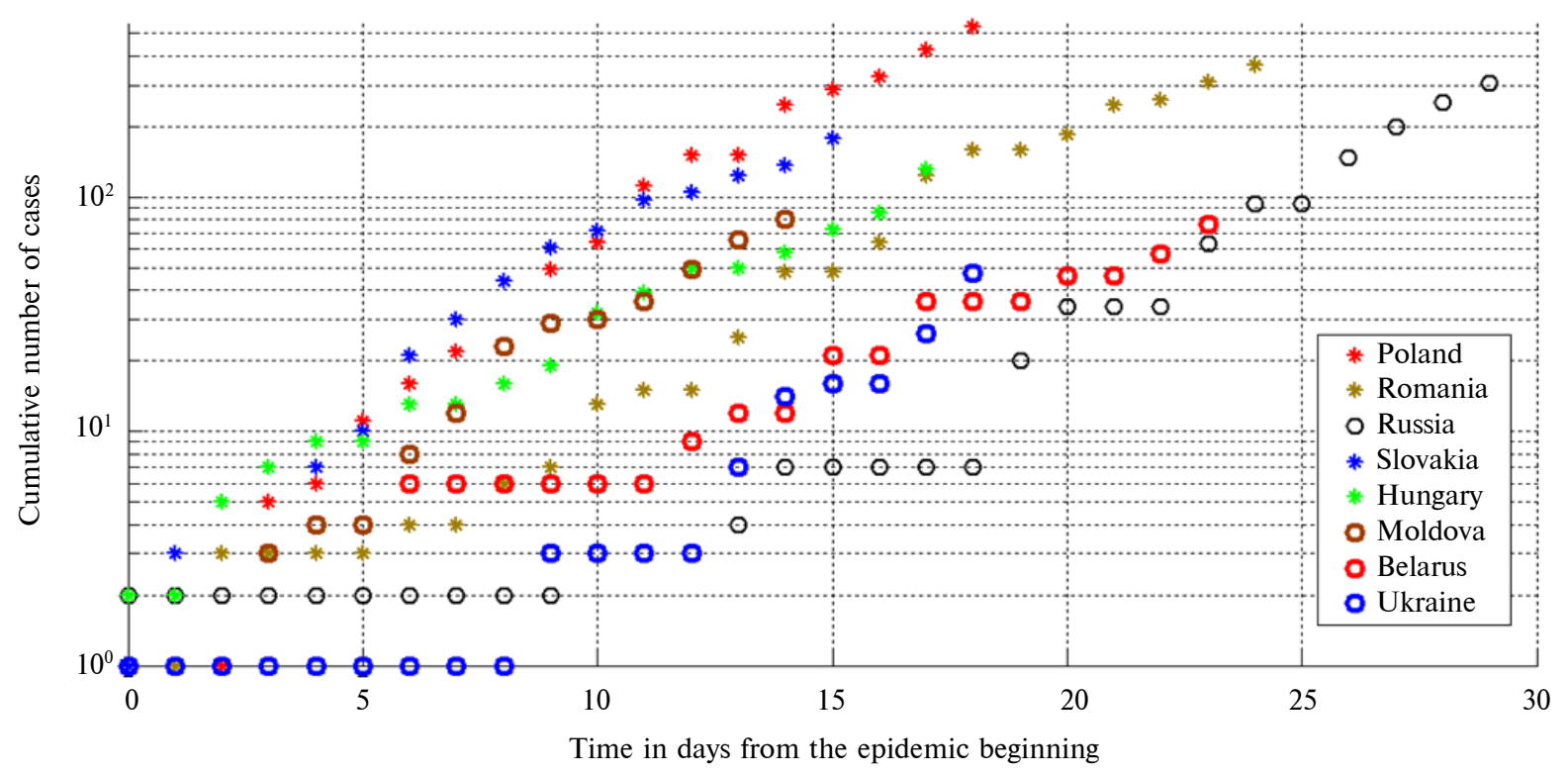

Fig. 3. The synchronized data sets for Ukraine and its neighboring countries versus time in days starting with the day when the first COVID-19 case was confirmed (logarithmic scale)

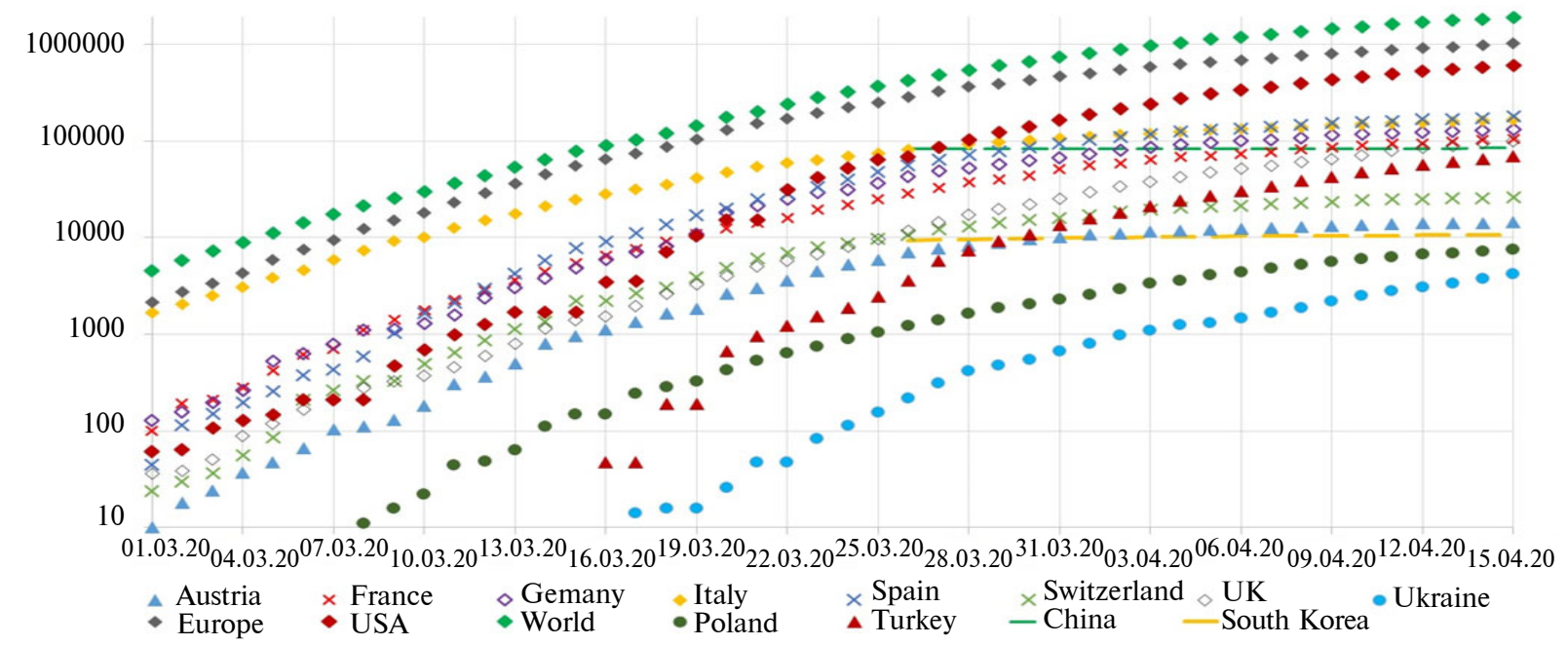

Fig. 4. The data sets for the accumulated confirmed number of cases versus time in days in March and April, 2020

We use the logarithmic scale to detect the periods of exponential growth which is typical for initial stage of every epidemic. Fig. 4 demonstrates the pandemic dynamics in the European region, USA and in the world. It can be seen that in April, 2020, the European and global dynamics (without cases in mainland China and the Republic of Korea) and the number of cases in USA showed deviation from the straight lines, i.e. the pandemic was stabilizing.

Many countries in Europe demonstrate clear stabilization. For example, we can see it in Fig 5, were the dynamics in Austria and its neighboring countries is shown. The final sizes and durations of the pandemic in Austria, Italy, Spain, Germany,
France and Moldova were estimated in [15] with the use of SIR model. Unfortunately, the number of cases in Italy, Spain, Germany, France and UK is higher than in China and in Turkey, Austria and Switzerland higher than in South Korea (see the horizontal lines in Fig. 4). In Slovenia, Hungary and Slovakia the final number of cases is expected to be rather low. It looks that quarantine measures and isolation of infected persons were very effective in these countries. Fig. 6 shows the pandemic dynamics in Ukraine and its neighboring countries. An evident stabilization is visible only in Poland, Hungary, Moldova and Slovakia. Some stabilization is visible also in Ukraine. The final size and the 


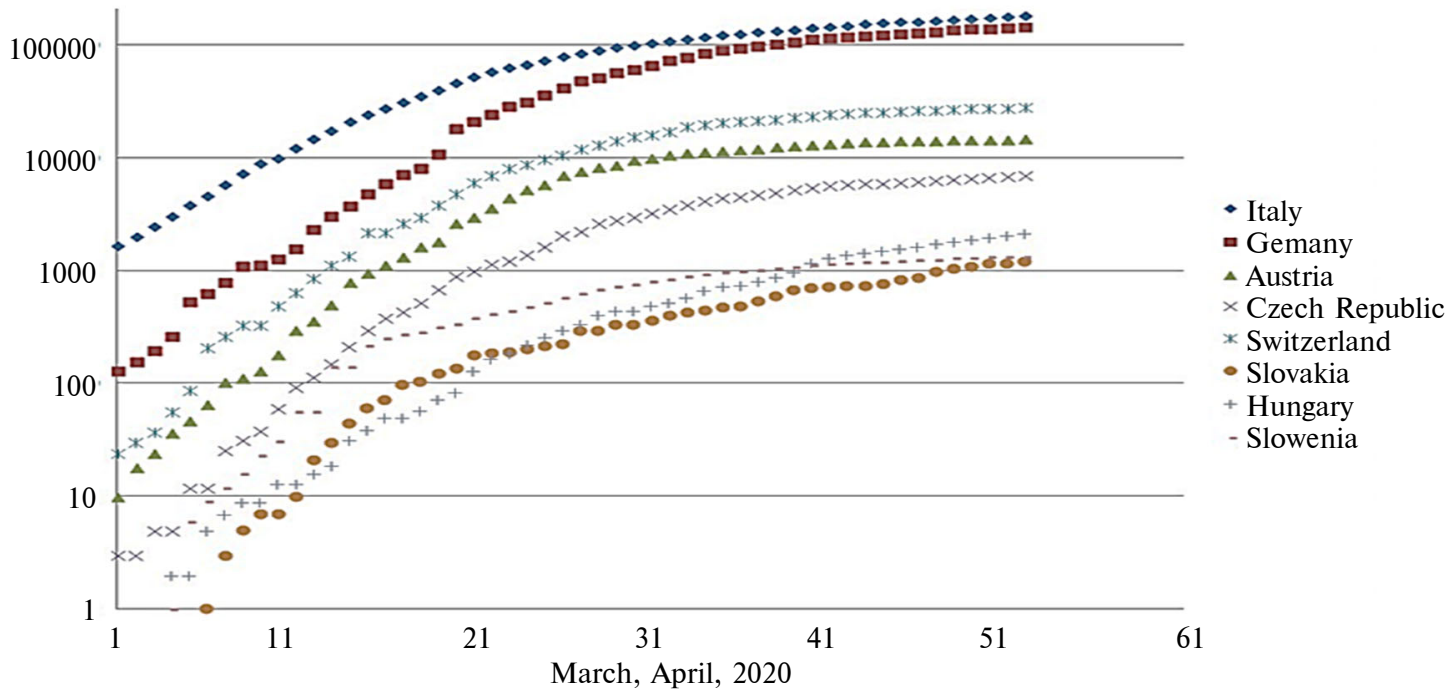

Fig. 5. Number of cases in Austria and its neighboring countries versus time in days in March and April, 2020

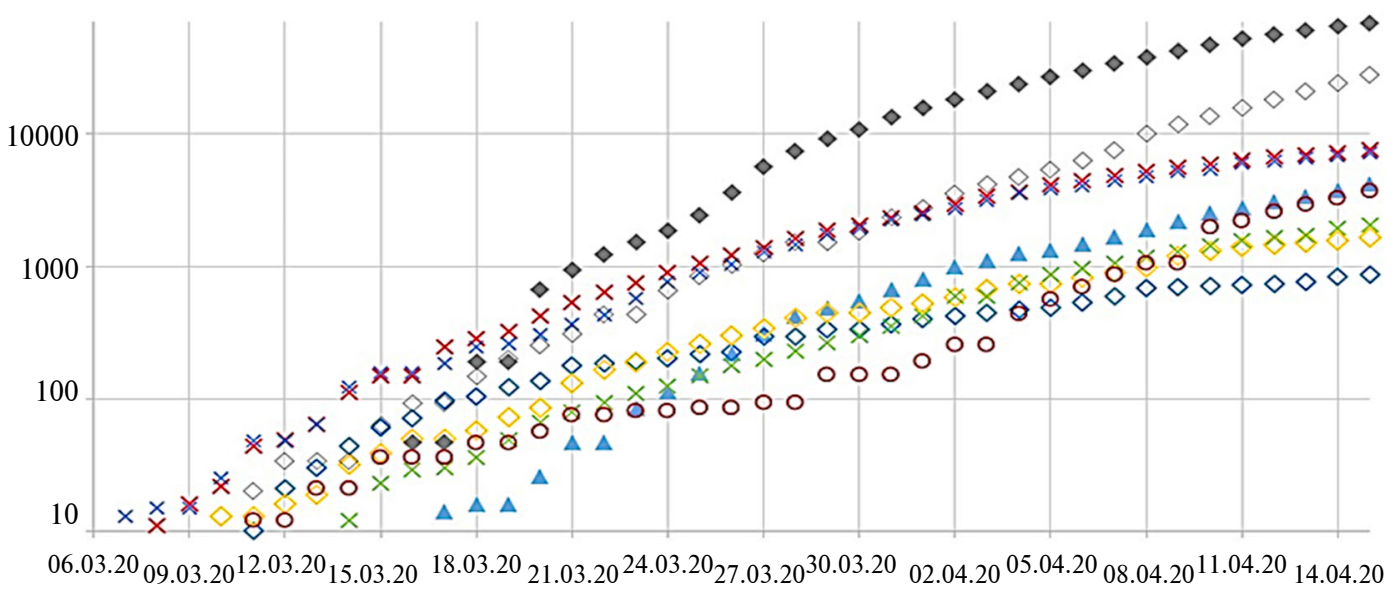

$\triangle$ Ukraine $\times$ Poland $\diamond$ Slovakia $\diamond$ Hungary $\times$ Romania $\times$ Moldova $\diamond$ RF $\circ$ Belarus $\diamond$ Turkey

Fig. 6. Number of cases in Ukraine and its neighboring countries versus time in days in March and April, 2020

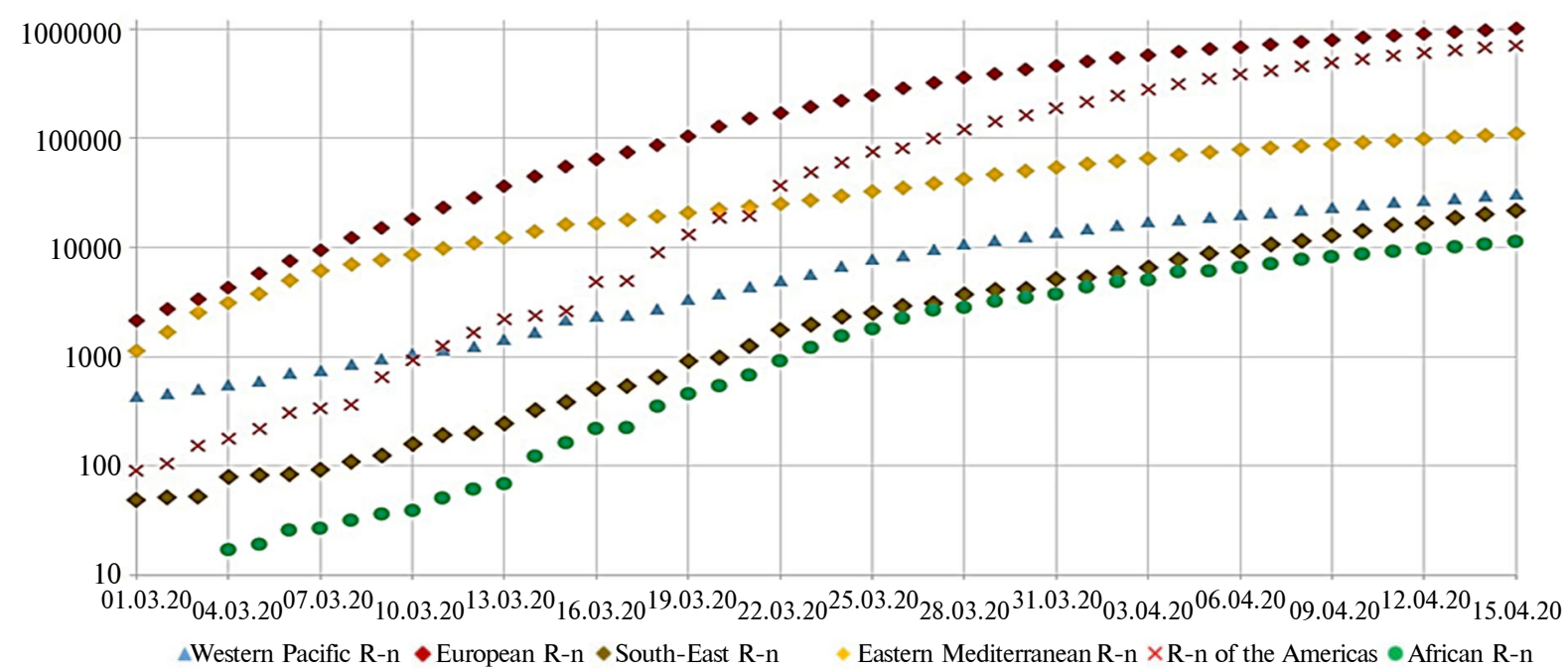

Fig. 7. Number of cases in different regions versus time in days in March and April, 2020 
saturation level for this country was predicted in [9] with the use of SIR model. The epidemics in Turkey, Belarus and RF are still far from stabilization.

Fig. 7 shows the pandemic dynamics in March and April, 2020 for different regions. It can be seen the stabilization in European, Eastern Mediterranean regions Americas and Africa. But the points for South-East Asia and Western Pacific regions still follow straight lines. Especially threatening is the situation in South-East Asia, where the exponential growth is rather rapid. Let us hope that quarantine and fast isolation of infected persons will change the situation in India and other countries of this region. It must be noted, that COVID-19 epidemic outbreaks can have very long hidden periods. For example, in Italy the first cases probably were not identified during 87 days (see [9]). It means that sudden and severe outbreak may happen in a country, there COVID-19 testing and isolation are bad organized.

\section{Conclusions}

The situation with the COVID-19 pandemic is still threatening. But may be the dynamics in April, 2020 gives some hope for its stabilization at least in the countries with proper quarantine measures, fast detection and isolation of sick persons. The final sizes and durations of epidemic can be very different for different countries. Repeated outbreaks are possible and already occurring, but they will no longer be so severe, primarily because we have learned to better identify and isolate infected persons.

\section{References}

[1] World Health Organization. "Coronavirus disease (COVID-2019) situation reports" [Online]. Available: https://www.who.int/emergencies/diseases/novel-coronavirus-2019/situation-reports/

[2] I. Nesteruk, "Coronavirus epidemic outbreak in Europe. Comparison with the dynamics in mainland China", KPI Sci. News, no. 1, pp. 15-17, 2020. doi: 10.20535/kpi-sn.2020.1.198043

[3] Y. Li et al., "COVID-19 epidemic outside China: 34 founders and exponential growth", MEDRXIV, Mar. 5, 2020. doi: $10.1101 / 2020.03 .01 .20029819$

[4] I. Nesteruk, "Comparison of the coronavirus pandemic dynamics in Europe, USA and South Korea", MEDRXIV, Mar., 2020. doi: $10.1101 / 2020.03 .18 .20038133$

[5] I. Nesteruk, "Statistics-based predictions of coronavirus epidemic spreading in mainland China", Innov. Bosyst. Bioeng., vol. 4, no. 1, pp. 13-18, 2020. doi:10.20535/ibb.2020.4.1.195074

[6] Y. Liu et al., "The reproductive number of COVID-19 is higher compared to SARS coronavirus", J. Travel Med., vol. 27, no. 2, 2020. doi: 10.1093/jtm/taaa021

[7] I. Nesteruk, "Stabilization of the coronavirus pandemic in Italy and global prospects", MEDRXIV, Apr., 2020. doi: $10.1101 / 2020.03 .28 .20045898$

[8] I. Nesteruk, "Long-term predictions for COVID-19 pandemic dynamics in Ukraine, Austria and Italy", MEDRXIV, Apr. doi: $10.1101 / 2020.04 .08 .20058123$

[9] I. Nesteruk, "SIR-simulation of Corona pandemic dynamics in Europe”, MEDRXIV, Apr., 2020. doi: 10.1101/2020.04.22.20075135

[10] A.J. Kucharski et al., "Early dynamics of transmission and control of COVID-19: a mathematical modelling study", The Lancet. Infectious Deseases, vol. 20, no. 5, 2020, pp. 553-558. doi: 10.1016/S1473-3099(20)30144-4

[11] I. Nesteruk, “Maximal speed of underwater locomotion”, Innov. Biosyst. Bioeng., 2019, vol. 3, no. 3, pp. $152-167$. doi: $10.20535 /$ ibb.2019.3.3.177976

\section{І.Г. Нестерук, І.Б. Кудибин, Г. Демельмайр}

\section{ТЕНДЕНЦІї ГЛОБАЛЬНОЇ СТАБІЛІЗАЦІЇ ПАНДЕМІї COVID-19}

Проблематика. Пандемія коронавірусу COVID-19 викликає велике занепокоєння. Детальний науковий аналіз цього явища ще попереду, але вже зараз необхідно терміново оцінити та порівняти динаміку захворювання з метою поліпшення карантинної діяльності та рівня індивідуального захисту, прискорення швидкості ізоляції інфрікованих тощо. У середині березня 2020 року BОО3 повідомила про різке експоненціальне збільшення кількості випадків захворювання на COVID-19 у світі. Тому вивчення динаміки пандемії продовжує привертати інтерес дослідників. Деякі роботи щодо порівняння динаміки епідемії в Італії, материковому Китаї, Іспанії, Німеччині, Франції, Швейцарії, США, Південній Кореї та щодо деяких глобальних тенденцій уже опубліковані. Однак отримання нових даних вимагає постійного аналізу динаміки пандемії.

Мета дослідження. У цій роботі ми порівнюємо динаміку пандемії в березні та квітні 2020 року для різних країн Європи, США, регіонів і в усьому світі та намагаємось оцінити деякі світові тенденції. 
Методика реалізації. Ми використовуємо офіційні дані про накопичену кількість підтверджених випадків COVID-19 у різних країнах та у всьому світі зі щоденних звітів ВООЗ. Для порівняння динаміки епідемій у різних країнах використовуються різні процедури синхронізації часу та порівняння з експоненціальним зростанням.

Результати дослідження. Для Італії, Іспанії, Німеччини, Швейцарії, Франції та США динаміка епідемії в березні 2020 року порівнювалася із ситуацією в Республіці Корея. Проаналізовано розвиток епідемії в Україні, Австрії, їхніх сусідніх країнах та світові тенденції.

Висновки. Ситуація з пандемією COVID-19 залишається загрозливою. Але, можливо, динаміка у квітні 2020 року дає певну надію на її стабілізацію, принаймні у країнах із належними карантинними заходами, швидким виявленням та ізоляцією хворих. Кінцеві розміри і тривалість епідемії можуть бути дуже різними для різних країн. Повторні спалахи можливі і вже трапляються, але вони вже не будуть такими важкими, насамперед тому, що ми навчилися краще ідентифікувати та ізолювати інфікованих осіб.

Ключові слова: пандемія коронавірусу COVID-19; коронавірус 2019-nCoV; статистичні методи.

\section{И.Г. Нестерук, И.Б. Кудибин, Г. Демельмайр}

\section{ТЕНДЕНЦИИ ГЛОБАЛЬНОЙ СТАБИЛИЗАЦИИ ПАНДЕМИИ COVID-19}

Проблематика. Пандемия коронавируса COVID-19 вызывает серьезную обеспокоенность. Подробный научный анализ этого явления еще впереди, но уже сейчас необходимо срочно оценить и сравнить динамику заболевания, чтобы улучшить карантинную деятельность и уровень индивидуальной защиты, чтобы ускорить изоляцию зараженных людей и т.д. В середине марта 2020 года ВОЗ сообщила о резком экспоненциальном увеличении числа случаев заболевания на COVID-19 в мире. Поэтому изучение динамики пандемии продолжает вызывать интерес исследователей. Некоторые работы относительно сравнения динамики эпидемии в Италии, Китае, Испании, Германии, Франции, Швейцарии, США, Южной Корее и относительно некоторых глобальных тенденций уже опубликованы. Однако получение новых данных требует постоянного анализа динамики пандемии.

Цель исследования. В этой статье мы сравниваем динамику пандемии в марте и апреле 2020 года для разных стран Европы, США, регионов и всего мира и пытаемся оценить некоторые глобальные тенденции.

Методика реализации. Мы используем официальные данные о накопленном количестве подтвержденных случаев COVID-19 в разных странах и во всем мире из ежедневных отчетов ВОЗ. Для сравнения динамики эпидемии в разных странах используются разные процедуры синхронизации времени и сравнение с экспоненциальным ростом.

Результаты исследования. Проведено сравнение динамики эпидемии в Италии, Испании, Германии, Швейцарии, Франции и США в марте 2020 года с ситуацией в Республике Корея. Были проанализированы развитие эпидемии в Украине, Австрии, соседних странах и глобальные тенденции.

Выводы. Ситуация с пандемией COVID-19 остается угрожающей. Но, возможно, динамика в апреле 2020 года дает некоторую надежду на ее стабилизацию, по крайней мере, в странах с надлежащими карантинными мерами, быстрым выявлением и изоляцией больных. Окончательные размеры и продолжительность эпидемии могут сильно отличаться для разных стран. Повторные вспышки возможны и уже происходят, но они больше не будут такими серьезными, в первую очередь потому, что мы научились лучше выявлять и изолировать инфицированных людей.

Ключевые слова: пандемия коронавируса COVID-19; коронавирус 2019-nCoV; статистические методы.

Рекомендована Радою

факультету прикладної математики

КПІ ім. Ігоря Сікорського
Надійшла до редакції

27 квітня 2020 року

Прийнята до публікації 05 червня 2020 року 